\title{
Sengketa Pemilihan Kepala Daerah: Studi Kasus Pemilihan Gubernur di Maluku Utara
}

\author{
Oleh: Riri Nazriyah \\ Alumni PascasarjanaFH UII Yogyakarta \\ e-mail: Ririesnaya@yahoo.com
}

\begin{abstract}
The direct residential as well as provincial election may pave the way for the enhancement of the quality of democracy. It is unfortunate however, that among those elections have raised the conflict and social unrest, which led to the lack of recognition of the elected candidates, and finally the cases then are brought to the court. Legal provisions pertaining to the way these disputes shall be settled are also have not yet been synchronized. This brings about that General Election Commission (KPU) as well as Local Election Commission (KPUD) and the Supreme Court (MA) hold their own legal interpretations which differs each from others.
\end{abstract}

Keywords: Sengketa, pemilihan Kepala daerah, Gubernur

\section{Pendahuluan}

Perkembangan berdemokrasi di daerah tumbuh luar biasa sejak lahirnya politik otonomi daerah yang bergulir begitu cepat. Seluruh kepala daerah dipilih secara langsung oleh rakyat sesuai dengan amanat undangundang yang lahir di era reformasi - kecuali jabatan Gubernur Daerah Istimewa Yogyakarta (DIY). Di beberapa daerah pelaksanaan Pemilihan Kepala Daerah (Pilkada) melahirkan ketidakpuasan yang berujung pada pengajuan keberatan atas hasil Pilkada tersebut ke pengadilan dengan alasan yang beragam.

Di Maluku Utara misalnya, penyelenggaraan Pemilihan Kepala Daerah telah menimbulkan kekacauan dan berakhir dengan menyisakan sejumlah permasalahan, bahkan pihak KPUD Maluku Utara dipandang tidak mampu melaksanakan Pemilihan Kepala Daerah sesuai dengan aturan yang berlaku. Hasil penghitungan suara yang diperoleh masingmasing calon pemilihan Kepala Daerah menimbulkan kontroversi. 
Akibatnya, Komisi Pemilihan Umum (KPU) Pusat mengambil alih untuk menghitung ulang hasil pemilihan kepala daerah Maluku Utara tersebut.

Intervensi KPU Pusat berawal dari keterangan KPU Provinsi Maluku Utara (Malut) dengan KPUD Kabupaten/Kota Malut terkait kesimpangsiuran penandatanganan dua dokumen. Ada dua dokumen sertifikat perhitungan suara yang sama, tetapi dengan angka perhitungan yang berbeda. Hal ini nampak aneh, karena sudah jelas angkanya berbeda, tetapi penandatanganannya sama. ${ }^{1}$ Akhirnya, KPU Pusat menetapkan hasil pemilihan kepala daerah Maluku Utara dan membatalkan penetapan KPUD Maluku Utara mengenai hasil pemilihan Gubernur dan Wakil gubernur Provinsi Maluku Utara.

Keputusan KPU dalam penyelesaian masalah Pilkada telah menimbulkan pro dan kontra, ada yang setuju dengan pengambilalihan Pilkada Maluku Utara dari KPUD Provinsi Maluku Utara, ada juga yang tidak setuju dengan keputusan KPU. Ketua KPU Abdul Hafiz Anshary menilai bahwa KPU Pusat mengambil alih kasus sengketa hasil perhitungan suara Pilgub Malut, sangat tepat. Sebab, KPUD Maluku Utara diindikasikan tidak mampu menjalankan tugas dan tanggung jawabnya dengan baik. Menurut Pasal 122 ayat (3) UU No. 22 Tahun 2007 tentang Penyelenggaraan Pemilu, KPU memang dimungkinkan mengambil alih tahapan pilkada. Hal senada dikatakan anggota Komisi II DPR Saifullah Maksum. Tindakan yang ditempuh KPU Pusat sudah tepat. Pasalnya, KPUD Maluku Utara diindikasikan tidak dapat menyelesaikan persoalan dan tanggung jawabnya dengan baik. Bahkan, dalam UU 22 Tahun 2007 dimungkinkan kewenangan KPU Pusat mengambil alih kasus KPUD.

Gubernur Lembaga Ketahanan Nasional (Lemhannas), Muladi, juga berpendapat sama, langkah Komisi Pemilihan Umum (KPU) mengambilalih rekapitulasi hasil Pemilihan Kepala Daerah Propinsi Maluku Utara (Malut) adalah tepat. “Langkah `take over' KPU merupakan langkah keberanian dan ada dasar hukumnya. Muladi mengatakan, apabila terjadi perselisihan suara dalam Pemilihan Kepala Daerah, langkah yang dapat ditempuh melalui pengadilan yakni Pengadilan Tinggi (PT). Namun, yang terjadi di Maluku Utara tidak hanya masalah selisih suara, karena ada dugaan terjadi permasalahan penghitungan suara dan secara organisatoris kurang dapat dibenarkan.

\footnotetext{
${ }^{1}$ Koran Sindo, 23 November 2007
} 
Sementara itu, Pakar Hukum Tata Negara Universitas Gadjah Mada, Denny Indrayana, mengatakan Keputusan Komisi Pemilihan Umum (KPU) yang membatalkan keputusan Komisi Pemilihan Umum Daerah (KPUD) Maluku Utara dinilai cacat hukum. Tidak ada satu aturan pun yang mengatur bahwa KPU bisa membatalkan keputusan KPUD. ${ }^{2}$ Lebih lanjut Denny mengatakan, berdasarkan Undang-Undang Penyelenggara Pemilihan Umum, pengambilalihan hanya dapat dilakukan jika KPUD dinilai tidak mampu untuk melaksanakan pemilihan kepala daerah (pilkada). Namun, dalam kasus ini KPUD Maluku Utara tidak bisa dikatakan tidak mampu menyelenggarakan pemilihan. Sebab semua proses Pilkada berjalan dan pemenangnya sudah ditetapkan. Itu berarti KPUD mampu menggelar pemilihan terlepas dari adanya sengketa. Denny berpendapat langkah yang diambil KPU keliru. Seharusnya, semua sengketa Pilkada diserahkan melalui proses hukum di Mahkamah Agung.

Direktur Monitoring dan Evaluasi Komite Independen Pemantau Pemilu (KIPP) Indonesia, Jojo Rohi menjelaskan, keputusan KPU mengambil alih kemelut Pilkada di Maluku Utara sebenarnya melanggar UU No 22 Tahun 2007 tentang Penyelenggaraan Pemilu. Tetapi di sisi lain, pengambilalihan dan keputusan cepat yang diambil oleh KPU untuk menghindari makin banyaknya lembaga lain yang ingin intervensi masalah Pilkada Maluku Utara. Andi Muhammad Asrun menilai KPU tidak berwenang membatalkan hasil Pilkada Maluku Utara, karena pembatalan hasil pilkada Gubernur/Wakil Gubernur hanya dapat dilakukan melalui gugatan ke Mahkamah Agung (MA).

Berdasarkan uraian di atas ada dua sengketa yang ditimbulkan dari penyelenggaraan Pilkada di Maluku Utara yaitu, pertama, sengketa kewenangan antara KPU Pusat dengan KPUD Maluku Utara dalam menetapkan pemenang Pilkada, kedua, sengketa hasil penghitungan suara.

\section{Pemilihan Kepala Daerah Langsung}

Pemilihan Kepala Daerah dan Wakil Kepala Daerah, baik Gubernur maupun Bupati/Walikota dan Wakil Bupati/Walikota, secara langsung oleh rakyat merupakan perwujudan pengembalian "hak-hak dasar" rakyat dalam memilih pemimpin di daerah. Dengan itu, rakyat memiliki kesempatan dan kedaulatan untuk menentukan pemimpin daerah secara

${ }^{2}$ Tempo, 23 November 2007 
langsung, bebas dan rahasia tanpa intervensi (otonom), seperti mereka memilih Presiden dan Wakil Presiden dan wakil-wakilnya di lembaga legislatif (Dewan Perwakilan Rakyat/DPR, Dewan Perwakilan Daerah/ DPD dan Dewan Perwakilan Rakyat Daerah/DPRD) dalam Pemilu 2004.

Dasar hukum mengenai pemilihan Kepala Daerah dan Wakil Kepala Daerah secara langsung diatur dalam Undang-Undang No. 32 Tahun 2004 tentang Pemerintahan Daerah. Sedangkan petunjuk pelaksanaannya tertuang dalam Peraturan Pemerintah No. 6 Tahun 2005 tentang Tata Cara Pemilihan, Pengesahan, Pengangkatan, dan Pemberhentian Kepala Daerah. Undang-undang Pemerintahan Daerah menentukan bahwa Kepala Daerah dan Wakil Kepala Daerah dipilih dalam satu pasangan calon yang dipilih melalui pemilihan umum yang dilaksananakan secara demokratis.

Argumentasi yang dikemukakan sebagai latar belakang perubahan fundamental mengenai pemilihan kepala daerah yaitu, pertama, Presiden dipilih secara langsung dalam pemilu yang dilakukan pertama kali melalui pemilu tahun 2004, sementara kepala desa juga dilaksanakan secara langsung, mengapa pemilihan kepala daerah tidak dilakukan secara langsung. Kedua, pemilu kepala daerah akan lebih mewujudkan kedaulatan yang berada di tangan rakyat, sebagaimana ketentuan Pasal 1 ayat (2) UUD 1945. Dengan adanya kedaulatan di tangan rakyat di pemerintahan daerah maka money politic tidak lagi banyak terjadi yang pada gilirannya nanti akan mempercepat kesejahteraan rakyat. Ketiga, secara yuridis, UU No 22 tahun 1999 menentukan bahwa kepala daerah dipilih oleh DPRD sudah tidak sesuai lagi karena undang-undang ini merupakan produk hukum sebelum amandemen UUD 1945. Sementara itu, sudah ada UU tentang Susduk MPR, DPR, DPD dan DPRD (UU No 22 tahun 2003) yang tidak menyebutkan adanya tugas dan wewenang DPRD untuk memilih kepala daerah. Hal ini ditafsirkan bahwa UU No 22 tahun 2003 menginginkan pemilihan kepala daerah dilakukan secara langsung. ${ }^{3}$

Pilkada langsung merupakan mekanisme demokratis dalam rangka rekrutmen pemimpin di daerah, di mana rakyat secara menyeluruh memiliki hak dan kebebasan untuk memilih calon-calon yang didukungnya, dan calon-calon yang bersaing dalam suatu medan permainan dengan aturan main yang sama. Sebab, sabagus apapun sebuah negara yang ditata secara demokratis, tidak akan dianggap benar-benar

${ }^{3}$ Morison, Hukum Tata Negara Era Reformasi, Ramdina Prakarsa, Jakarta, 2005, hlm. 199-200 
demokratis manakala pemimpin-pemimpinnya tidak dipilih secara bebas oleh rakyatnya sendiri. Pemilihan selalu dijadikan tolak ukur untuk menentukan sebuah negara demokratis atau tidak. Demokrasi memang tidak semata-mata ditentukan oleh ada tidaknya pemilihan oleh rakyat atas pemimpin-pemimpinnya. Pemilihan memerlukan perangkat lain untuk mendukung proses pemilihan. ${ }^{4}$

Sejalan dengan sistem demokrasi perwakilan, maka secara kelembagaan perlu ada badan perwakilan rakyat daerah yang dibentuk secara demokratik. Demikian pula penyelenggaraan pemerintahannya harus dijalankan secara demokratik yang meliputi tata cara penunjukan pejabat, penentuan kebijakan, pertanggungjawaban, pengawasan, dan lain-lain. mekanisme pemerintahan harus dilakukan dengan tata cara yang demokratik pula. ${ }^{5}$

Axel Hadenis ${ }^{6}$ mengatakan bahwa suatu pemilu, termasuk pemilihan kepala daerah langsung, disebut demokratis kalau memiliki "makna”. Istilah "bermakna" merujuk pada tiga kriteria, yaitu (1) keterbukaan, (2) ketepatan dan (3) keefektifan pemilu.Ketiga kriteria tersebut harus dipenuhi bukan hanya pada saat pemungutan suara saja, melainkan juga sewaktu dilakukan kampanye dan penghitungan suara. Akhirnya, kriteria itu juga berarti Kepala Daerah yang dipilih benar-benar akan menduduki jabatannya.

Keterbukaan mengandung tiga maksud bahwa akses pada pilkada harus terbuka bagi setiap warga negara (universal suffrage, atau hak pilih universal), ada pilihan dari antara alternatif-alternatif politik riil (para calon yang berkompetisi), dan bahwa hasilnya tidak ditentukan sebelumnya. Akses warga yang terbuka berarti hak pilih benar-benar bersifat universal. Seluruh warga negara dijamin memiliki hak pilih tanpa diskriminasi. Bukan merupakan kontroversi atau kontradiksi apabila hak untuk memilih dibatasi dengan syarat-syarat minimal yang harus dipenuhi warga, seperti usia, kesehatan jasmani dan rohani, domisili, dan lamanya bermukim. Keterbukaan juga berarti persamaan nilai suara dari seluruh warga negara tanpa terkecuali. Prinsip yang biasa digunakan adalah one person, one vote, one value.

\footnotetext{
${ }^{4}$ Jimly Asshiddiqie,"Pemilihan Langsung Presiden dan Wakil Presiden," Jurnal Unisia No 51/XXVII/I/2004, hlm. 10 dalam Ni'matul Huda, Otonomi Daerah Filosofi, Sejarah Perkembangan dan Problematika, Cetakan I, Pustaka Pelajar, Yogyakarta, 2005, hlm. 204.

${ }^{5}$ Bagir Manan, Menyongsong Fajar Otonomi Daerah, Cet. III, FH UII Yogyakarta, 2004, hlm. 59

${ }^{6}$ Joko J. Prihatmoko, Pemilihan Kepala Daerah Langsung Filosofi, Sistem dan Problema Penerapan di Indonesia, Cetakan I, kerja sama Pustaka Pelajar dengan LP3M Universitas Wahid Hasyim Semarang, Yogyakarta, 2005, hlm. 112-115
} 
Kriteria mengenai ketepatan bertujuan pada pendaftaran dan identifikasi pemilih, kampanye dan prosedur pemilu dalam pengertian lebih ketat, yaitu semua calon harus mempunyai akses yang sama kepada media negara dan swasta berdasarkan standar-standar hukum yang sama, aparat negara harus netral secara politis pada saat meyelenggarakan Pilkada.

Kedaulatan rakyat mengandung di dalamnya pengertian bahwa Pilkada langsung harus" efektif". Itu berarti jabatan kepala eksekutif atau anggota legislatif harus diisi semata-mata dengan pemilu. Prinsip efektifitas Pilkada langsung dilanggar apabila akses pada posisi pusat kekuasaan diatur sebagian saja atau sama sekali malah tidak diatur oleh pemilu, melainkan semata-mata pengangkatan/penunjukan. Kriteria itu lebih lanjut mensyaratkan bahwa sistem bahwa Pilkada langsung harus mampu untuk menerjemahkan preferensi pemilih menjadi kursi. Hal itu mengukur tingkat disproporsionalitas sistem Pilkada langsung.

Namun demikian, perlu di garis bawahi bahwa pemilihan Kepala Daerah secara langsung tidak dengan serta merta menjalin peningkatan kualitas demokrasi itu sendiri. Demokrasi pada tingkat lokal membutuhkan berbagai persyaratan. Dalam perspektif itu, efektifitas sistem Pilkada langsung ditentukan oleh faktor-faktor atau sebutlah prakondisi demokrasi yang ada di daerah itu sendiri. Prakondisi demokrasi tersebut mencakup kualitas pemilih, kualitas dewan, sistem rekrurmen dewan, fungsi partai, kebebasan dan konsistensi pers, dan pemberdayaan masyarakat madani, dan sebagainya.

Pilkada langsung tidak dengan sendirinya menjamin peningkatan kualitas demokrasi itu sendiri tetapi jelas membuka akses terhadap peningkatan kualitas demokrasi tersebut. Akses itu berarti berfungsinya mekanisme check and balances. Dimensi check and balances meliputi hubungan $\mathrm{KDH} / \mathrm{WKDH}$ dengan rakyat; DPRD dengan rakyat; $\mathrm{KDH} /$ WKDH dengan DPRD; DPRD dengan $\mathrm{KDH} / \mathrm{WKDH}$ tetapi juga $\mathrm{KDH} /$ WKDH dan DPRD dengan lembaga yudikatif dan Pemerintah Daerah dengan Pemerintah Pusat. ${ }^{7}$

Tujuan utama Pilkada langsung adalah penguatan masyarakat dalam rangka peningkatan kapasitas demokrasi di tingkat lokal dan peningkatan

${ }^{7}$ Joko Prohatmoko, Pilkada Langsung Solusi Kemacetan Demokrasi, dalam Ari Pradhanawati (Penyunting), Pilkada Langsung Tradisi Baru Demokrasi Lokal, Cetakan Pertama, Konsorsium Monitoring dan Pemberdayaan Institusi Publik (KOMPIP), Surakarta, 2005, hlm. 176. 
harga diri masyarakat yang sudah sekian lama dimarginal. Selama ini, elit politik begitu menikmati kue kekuasaan. Tak mudah bagi mereka, khususnya anggota DPRD, merelakan begitu saja kekuasaan tersebut untuk dibagi-bagikan dengan rakyat walaupun rakyatlah penguasa kedaulatan dalam arti sesungguhnya. ${ }^{8}$

Pemilihan Kepala Daerah secara langsung di samping memiliki kelebihan juga terdapat beberapa kelemahan. Kelemahan-kelemahan pilkada langsung, yaitu: (1)Dana yang dibutuhkan besar. Dana atau anggaran yang dibutuhkan dalam Pilkada langsung sangat besar, baik untuk kegiatan operasianal, pembiayaan logistik maupun keamanan. Besarnya dana untuk Pilkada langsung memberatkan pemerintah daerah, apalagi jika pilkada menggunakan sistem dua putaran (two round atau run-off system), di tengah keharusan mengalokasian dana untuk kebutuhan rutin pembelanjaan pegawai yang sangat tinggi. Dengan lain kata, penyelenggaraan pilkada bisa menyedot dana yang seharusnya dapat dinikmati rakyat secara langsung. (2) Membuka kemungkinan konflik elite dan massa. Konflik terbuka akibat penyelenggaraan pilkada langsung sangat terbuka. Konflik yang terjadi dalam pilkada langsung bisa bersifat elite namun lebih besar kemungkinannya bersifat massa yang horizontal, yakni konflik antarmassa pendukung. Potensi konflik semakin besar dalam masyarakat paternalistik dan primordial, di mana pemimpin dapat memobilisasi pendukungnya. (3) Aktivitas rakyat terganggu. Kesibukan warga menjalankan aktivitas sehari-hari dengan mudah bisa terganggu karena pelaksanaan pilkada langsung. Mereka tidak hanya dihadapkan dengan kesulitan menyiasati kampanye para calon, namun juga energi dan pikirannya tersedot oleh isu-isu dan manuver yang dilakukan para calon.

Sedangkan kelebihan pilkada langsung dapat dipaparkan sebagai berikut: (1) Kepala daerah terpilih akan memiliki mandat dan legitimasi yang sangat kuat karena didukung oleh suara rakyat yang memberikan suara secara langsung. Legitimasi merupakan hal yang sangat diperlukan oleh suatu pemerintahan yang sedang mengalami krisis politik dan ekonomi. Krisis legitimasi yang telah menggerogoti kememimpinan atau kepala daerah akan mengakibatkan ketidakstabilan politik dan ekonomi di daerah. (2) Kepala Daerah terpilih tidak perlu terikat pada konsesi partai-partai atau faksi-faksi politik yang telah mencalonkannya. Artinya,

\footnotetext{
${ }^{8}$ Ibid., hlm. viii
} 
Kepala Daerah terpilih berada di atas segala kepentingan dan dapat menjembatani berbagai kepentingan tersebut. Apabila Kepala Daerah terpilih tidak dapat mengatasi kepentingan-kepentingan partai politik, maka kebijakan yang diambil cenderung merupakan kompromi kepentingan partai-partai dan acapkali berseberangan dengan kepentingan rakyat. Kebutuhan pemerintah daerah sekarang adalah kebijakan publik yang benar-benar berpihak pada rakyat. (3) Sistem pilkada langsung lebih akuntabel dibanding sistem lain yang selama ini digunakan karena rakyat tidak harus menitipkan suaranya kepada anggota legislatif atau electoral college secara sebagian atau penuh. Rakyat dapat menentukan pilihannya berdasarkan kepentingan dan penilaian atas calon. Apabila Kepala daerah terpilih tidak memenuhi harapan rakyat, maka dalam pemilihan berikutnya, calon yang bersangkutan tidak akan dipilih kembali. Prinsip ini merupakan prinsip pengawasan serta akuntabilitas yang paling sederhana dan dapat dimengerti baik oleh rakyat maupun politisi. (4) Checks and balances antara lembaga legislatif dan eksekutif dapat lebih seimbang. (5) Kriteria calon Kepala Daerah dapat dinilai secara langsung oleh rakyat yang akan memberikan suaranya.

Di samping pilkada langsung ada yang disebut pilkada tidak langsung. Faktor yang membedakannya adalah pertama, bagaimana partisipasi politik rakyat dilaksanakan atau diwujudkan kedua, melihat tahapantahapan kegiatan yang digunakan. Dalam pilkada tak langsung, partisipasi rakyat dalam tahapan-tahapan kegiatan sangat terbatas atau bahkan tidak ada sama sekali. Rakyat ditempatkan sebagai penonton proses pilkada yang hanya melibatkan elite. Rakyat hanya menjadi objek politik, misalnya kasus dukung-mendukung. Penonjolan peran partisipasi terletak pada elite politik, baik DPRD atau pejabat pusat. Dalam pilkada langsung, keterlibatan rakyat dalam tahapan-tahapan kegiatan sangat jelas terlihat dan terbuka lebar. Rakyat merupakan subjek politik. Mereka menjadi pemilih, penyelenggara, pemantau, dan bahkan pengawas. Oleh sebab itu, dalam pilkada langsung, selalu ada tahapan kegiatan pendaftaran pemilih, kampanye, pemungutan dan penghitungan suara, dan sebagainya.

Pilkada berdasarkan UU No. 32 Tahun 2004 memenuhi syarat disebut sebagai pilkada langsung karena dilaksanakan dengan kegiatan-kegiatan yang melibatkan rakyat sebagai pemilih, memberikan kesempatan kepada masyarakat melalui partai politik untuk menjadi calon, menjadi penyelenggara, dan mengawasi jalannya pelaksanaan kegiatan. 
Kegiatan pilkada langsung dilaksanakan dalam 2 tahap, yakni masa persiapan dan tahap pelaksanaan. Sebagaimana dikatakan dalam Pasal 65 ayat (1) UU No 32 Tahun 2004, pilkada dilaksanakan melalui masa persiapan dan tahap pelaksanaan. Masing-masing tahap dilakukan berbagai kegiatan yang merupakan proses pilkada langsung. Dalam Pasal 65 ayat (2) disebutkan kegiatan-kegiatan yang tercakup dalam masa persiapan, yakni:a) Pemberitahuan DPRD kepada kepala daerah mengenai berakhirnya masa jabatan; b) Pemberitahuan DPRD kepada KPUD mengenai berakhirnya masa jabatan kepala daerah; c) Perencanaan penyelenggaraan, meliputi penetapan tata cara dan jadwal tahapan pelaksanaan pemilihan kepala daerah; d) Pembentukan Panitia Pengawas, PPK, PPS dan KPPS; e) Pembentukan dan pendaftaran pemantau.

Dalam kegiatan masa persiapan, keterlibatan rakyat sangat menonjol dalam pembentukan Panitia Pengawas, PPK, PPS dan KPPS. Rakyat memiliki akses untuk memantau melalui mekanisme uji publik namun mendaftarkan diri sebagai anggota Panitia Pengawas, PPK,PPS dan KPPS. Sementara itu, tahap pelaksanaan terdiri dari 6 kegiatan, yang masing-masing merupakan rangkaian yang saling terkait. Sesuai Pasal 65 ayat (3) tahap

pelaksanaan pilkada meliputi: a) Penetapan daftar pemilih; b) Pendaftaran dan penetapan calon kepala daerah/wakil kepala daerah; c) Kampanye; d) Pemungutan suara; e) Penghitungan suara; dan f) Penetapan pasangan calon kepala daerah/wakil kepala daerah terpilih, pengesahan, dan pelantikan.

\section{Penyelenggara Pilkada Langsung}

Fungsi utama penyelenggara adalah merencanakan dan menyelenggarakan tahapan-tahapan kegiatan. Fungsi tersebut bisa optimal apabila dilengkapi mekanisme kontrol dan pertanggungjawaban sehingga dibutuhkan pengawasan. Ada 3 (tiga jenis pengawasan, yakni pengawasan internal, semi-eksternal dan eksternal. Pengawasan internal dilaksanakan melalui mekanisme organisasi yang bersifat struktural dalam bentuk supervisi dan pengambilan keputusan yang bersifat kolektif kolegial melalui mekanisme pleno. Pengawasan eksternal diwujudkan melalui pemantauan dan pengawasan oleh masyarakat, partai politik, pers, dan aktivis Lembaga Swadaya Masyarakat (LSM). Sedangkan pengawasan semi-eksternal dilakukan dengan pembentukan lembaga pengawasan yang mandiri, otonom dan independen namun berada di dalam struktur penyelenggara yang bertugas mengawasi pelaksanaan 
tahapan-tahapan kegiatan. Fungsi utama lembaga pengawas dalam mengoptimalkan penyelenggaraan tahapan-tahapan kegiatan.

Berbeda dengan penyelenggaraan pemilu legislatif dan pemilu Presiden dan Wakil Presiden yang memposisikan KPU - yang bersifat nasional, tetap dan mandiri sebagai pemegang mandat tunggal penyelenggaraan, UU No. 32 Tahun 2004 membagi kewenangan penyelenggaraan pilkada langsung kepada tiga institusi, yakni DPRD, KPUD dan Pemerintah Daerah. Secara fungsional, kedudukan ketiga institusi tersebut berbeda menurut tugas dan wewenangnya.

\section{DPRD merupakan pemegang otoritas politik}

Dimaksud dengan pemegang otoritas politik adalah bahwa DPRD merupakan representasi rakyat yang memiki kedaulatan dan memberikan mandat penyelenggaraan pilkada langsung, berwujud pemberitahuan mengenai berakhirnya masa jabatan kepala daerah kepada kepala daerah dan KPUD. Karena mekanisme itu bersifat politis, prosedur tersebut berimplikasi pada kekuatan hukum penyelenggaraan namun tidak berimplikasi pada pertanggungjawaban secara hukum. Karena KPUD harus bersifat mandiri, independen dan non-partisan, maka pertangungjawabannya kepada publik. Mekanismenya adalah penyampaian laporan pelaksanaan tahapan kegiatan ke DPRD. Penilaian politis DPRD dilakukan terhadap kinerja (baik dan buruk) KPUD. Kritik, saran dan aspirasi rakyat disampaikan DPRD dengan tujuan memperbaiki kinerja KPUD. Dengan demikian, penilaian DPRD tidak memiliki implikasi hukum, misalnya membatalkan tahapan kegiatan atau membubarkan KPUD. Masih sebagai pemegang otoritas politik yang merupakan representasi rakyat, DPRD juga menyelenggarakan rapat paripurna untuk mendengarkan penyampaian visi, misi, dan program dari pasangan calon kepala daerah dan wakil kepala daerah. Tujuannya, agar DPRD dan rakyat mengenal visi, misi dan program calon dengan baik.

\section{KPUD sebagai pelaksana teknis}

Sebagai pemegang mandat penyelenggaraan, KPUD secara teknis bertugas melaksanakan tahapan-tahapan kegiatan, dari tahap pendaftaran pemilih sampai penetapan calon terpilih. KPUD juga membuat regulasi (aturan), mengambil keputusan, dan membuat kebijakan yang harus sesuai dengan koridor hukum dan ketentuan perundangan. 


\section{Pemerintah Daerah menjalankan fungsi fasilitasi}

Pemerintah Daerah berkewajiban memberikan fasilitasi proses pilkada langsung meliputi bidang anggaran, personalia, dan kebijakan sebagai eksekutif. Selain itu, ada beberapa tugas teknis yang harus dilaksanakan untuk menunjang pelaksanaan tahapan kegiatan.

Konstruksi penyelenggara pilkada langsung tersebut memperlihatkan semangat otonomi daerah atau desentralisasi. KPUD tidak memiliki hubungan struktural baik dengan DPRD dan Pemerintah Daaerah maupun KPU. KPUD merupakan penyelenggara pilkada langsung tertinggi di daerah wilayahnya. KPUD tidak bertanggungjawab secara hukum kepada DPRD dan Pemerintah Daerah. Dalam pemilihan Bupati/Wakil Bupati dan Walikota/Wakil Walikota, KPUD Kabupaten/Kota adalah penyelenggaran tertinggi dan tidak bertanggungjawab kepada KPUD Propinsi atau KPU. Dalam pemilihan Gubernur/Wakil Gubernur, KPUD Propinsi menjadi peyelenggara tertinggi dan tidak bertangungjawab kepada KPU. Dalam pemilihan Gubernur/Wakil Gubernur, KPUD Kabupaten/Kota menjadi bagian yang harus memberikan pertanggungjawaban teknis kepada KPUD Propinsi. Tanggung jawab politis KPUD adalah kepada publik melalui DPRD sehingga KPUD menjadi penyelenggara yang benar-benar independen, mandiri dan non-partisan.

Dalam Pasal 66 UU No 32 tahun 2004 menegaskan bahwa, Tugas dan wewenang KPUD dalam penyelenggaraan pemilihan kepala daerah dan wakil kepala daerah adalah: a).merencanakan penyelenggaraan pemilihan kepala daerah dan wakil kepala daerah; b).menetapkan tata cara pelaksanaan pemilihan kepala daerah dan wakil kepala daerah sesuai dengan tahapan yang diatur dalam peraturan perundang-undangan; c). mengkoordinasikan, menyelenggarakan, dan mengendalikan semua tahapan pelaksanaan pemilihan kepala daerah dan wakil kepala daerah; d). menetapkan tanggal dan tata cara pelaksanaan kampanye, serta pemungutan suara pemilihan kepala daerah dan wakil kepala daerah; e). meneliti persyaratan partai politik atau gabungan partai politik yang mengusulkan calon; f). meneliti persyaratan calon kepala daerah dan wakil kepala daerah yang diusulkan; g). menetapkan pasangan calon yang telah memenuhi persyaratan; h). menerima pendaftaran dan mengumumkan tim kampanye; i). mengumumkan laporan sumbangan dana kampanye; j). menetapkan hasil rekapitulasi penghitungan suara dan mengumumkan hasil pemilihan kepala daerah dan wakil kepala daerah; k). melakukan evaluasi dan pelaporan pelaksanaan pemilihan 
kepala daerah dan wakil kepala daerah; 1). melaksanakan tugas dan wewenang lain yang diatur oleh peraturan perundang-undangan; $\mathrm{m}$. menetapkan kantor akuntan publik untuk mengaudit dana kampanye dan mengumumkan hasil audit.

Dengan demikian, peran KPUD dalam penyelenggaraan Pilkada pada dasarnya tidak sebatas sebagai penyelenggara saja, tetapi juga sebagai regulator dalam membuat keputusan-keputusan yang menyangkut tahapan persiapan dan pelaksanaan Pilkada dengan berpedoman pada perundang-undangan yang ada.

\section{Sengketa Pilkada di Maluku Utara}

Hasil pemilihan Kepala Daerah yang diselenggarakan pada tanggal 3 November 2007 telah diumumkan oleh Ketua Komisi Pemilihan Umum (KPUD) Provinsi Maluku Utara, M Rahmi Husen, bahwa pasangan Thaib Armaiyn-Abdul Gani dinyatakan sebagai pemenang pemilihan Gubernur dan Wakil Gubernur Provinsi Maluku Utara untuk periode 2007-2012. Hal itu sesuai rapat pleno KPUD Maluku Utara tanggl 16 November 2007 yang menetapkan jumlah rekapitulasi perhitungan suara pilihan Gubernur dan Wakil Gubernur yakni, pasangan Anthony Sunarjo - Drakel memperoleh 76.117 suara (15,88 persen), Thaib Armaiyn - Abdul Gani Kasuba 179.020 suara (37,35 persen), Abdul Gafur - AR Fabanyo 178.157 suara (37,17 persen) dan Irvan Eddison - Ati Achmad memperoleh 45.983 suara (9,59 persen). Dengan demikian berdasarkan SK KPU Propinsi Maluku Utara No.20/KEP/PG/PGWG/2007 tanggal 16 November 2007, telah ditetapkan pasangan dengan nomor 2 yakni Thaib Armaiyn - Abdul Gani Kasuba sebagai pasangan calon terpilih dengan perolehan suara 37,35 persen.

Penetapan pasangan Thaib Armaiyn - Abdul Gani Kasuba sebagai Gubernur dan Wakil Gubernur Maluku Utara tersebut telah menimbulkan persoalan sebab, kontroversi hasil suara muncul di 3 kecamatan, yakni Jailolo, Ibu Selatan dan Suhu Timur, semuanya terletak di Kabupaten Halmahera Barat, diduga telah terjadi penggelembungan suara. Pada tanggal 19 November KPU Pusat mengadakan rapat pleno tentang Penyelesaian Masalah Penyelenggara Pemilihan Umum Gubernur dan Wakil Gubernur Provinsi Maluku Utara tahun 2007. Berdasarkan Keputusan rapat pleno KPU Pusat tersebut, tanggal 20 November 2007 KPU Pusat telah menghitung ulang hasil pemungutan suara Pemilihan 
Kepala Daerah Provinsi Maluku Utara sekaligus menetapkan Gubernur dan Wakil Gubernur Provinsi Maluku Utara. Penghitungan tersebut dilakukan pada hasil pemungutan suara di tingkat kabupaten terkait polemik dugaan penggelembungan suara yang terjadi di pilkada yang diadakan pada 3 November 2007. KPU Pusat juga menonaktifkan Ketua KPUD Provinsi Maluku Utara M Rahmi Husen dan salah satu anggotannya Nurbaya Soleman, alasan pemberhentian, adanya pelanggaran janji dan sumpah jabatan. Selain itu dua orang tersebut dianggap tidak mematuhi petunjuk KPU Pusat dalam menyelesaikan kekisruhan Pilkada Maluku Utara. ${ }^{9}$ KPU Pusat pun mengambil alih tugas dan wewenang KPUD Provinsi Maluku Utara mulai saat keputusan pleno tersebut dibacakan ( 19 November 2007).Alasan mengambil alih kewenangan tersebut di antaranya karena tahapan pilkada tidak berjalan dengan baik, dan tingkat kepercayaan rakyat terhadap KPU Provinsi sangat rendah, karena rapat yang diselenggarakan oleh KPU Provinsi beberapa kali mengalami deadlock (jalan buntu) sehingga rawan terjadi konflik. ${ }^{10}$ Tidak hanya itu, KPU Pusat yang diketuai oleh Hafiz Anshari juga membatalkan keputusan KPUD Provinsi Maluku Utara yang membekukan KPUD Kabupaten Halmahera Barat. ${ }^{11}$

Berdasarkan rapat pleno tanggal 22 November 2007 KPU Pusat kemudian menetapkan kemenangan Abbul Gafur - AR Fabanyo dengan perolehan suara 181.889 suara atau selisih 2.869 suara dari Thaib Armaiyn - Absul Gani Kasuba. Dengan demikian melalui surat keputusan KPU Pusat mengenai penetapan pasangan calon terpilih Gubernur/Wakil Gubernur Maluku Utara bernomor 158/SK/KPU/2007 tertanggal 26 November 2007 Abdul Gafur - AR Fabanyo dinyatakan sebagai Gubernur/ Wakil Gubernur Provinsi Maluku Utara. ${ }^{12}$

Sengketa Pilkada Provinsi Maluku Utara bermula ketika Komisi Pemilihan Umum (KPU) Pusat membatalkan keputusan Komisi Pemilihan Umum Daerah (KPUD) yang memenangkan pasangan calon Gubernur dan Wakil Gubernur Thaib Armaiyn dan Gani Kasuba. Pertanyaannya, berwenangkah KPU Pusat melakukan penghitungan ulang hasil pemungutan suara Pemilihan Kepala Daerah, menetapkan pemenang

\footnotetext{
${ }^{9}$ http:/ / www.tempointeraktif.com.

${ }^{10} \mathrm{http}: / /$ bintannews.com

${ }^{11}$ www.Kabarindonesia. Com.20 November 2007, 13:35:50 WIB.

${ }^{12}$ http.www/Republika.co.id
} 
Pilkada, mengambil alih wewenang KPUD Provinsi Maluku Utara, dan membatalkan keputusan Komisi Pemilihan Umum Daerah (KPUD) ?

Secara teoritis, intervensi pusat kepada daerah memang dapat dibenarkan, yaitu apabila terjadi kemacetan dalam proses demokrasi. Yang dimaksud dengan kemacetan demokrasi adalah apabila elit daerah, baik eksekutif (birokrat) maupun legislatif (politisi), melakukan konspirasi dengan mengabaikan aspirasi dan kepentingan rakyat daerah untuk kepentingan kelompok elit itu sendiri. Apabila hal itu yang terjadi, maka campur tangan pusat, baik pemerintah pusat maupun pimpinan pusat partai politik dapat dibenarkan dengan argumen untuk melindungi kepentingan rakyat. ${ }^{13}$

Dalam soal pengambilalihan, KPU menggunakan Pasal 122 ayat (3) UU No 22 Tahun 2007 yang menyebutkan bahwa apabila terjadi hal-hal yang mengakibatkan KPU Provinsi atau KPU Kabupaten/Kota tidak dapat menjalankan tugasnya, tahapan penyelenggaraan Pemilu untuk sementara dilaksanakan oleh KPU setingkat di atasnya. Persoalannya, KPU Provinsi Maluku Utara berhasil menjalankan tugasnya, bahkan sudah mengumumkan pemenang Pilkada. Jadi, tidak ada kriteria yang membuktikan bahwa KPU Provinsi Maluku Utara tidak dapat menjalankan tugasnya, karena telah dibuktikan dengan selesainya semua tahapan Pilkada sampai dikeluarkannya Keptusan KPU Provinsi Maluku Utara No. 20/Kep/PGWG/2007 pada tanggal 16 November 2007, KPUD Malut telah menetapkan pasangan Thaib-Abdul sebagai pemenang pilkada Gubernur Malut. Kalaupun terjadi persoalan, KPU belum bisa langsung mengambil alih, tanpa konsideran yang jelas pada alasan apa pengambilalihan itu dilakukan. Penonaktifan dua orang anggota KPU Provinsi Maluku Utara tidak dengan sendirinya menyebabkan KPU Provinsi Maluku Utara tidak dapat menjalankan tugasnya. Yang dinonaktifkan adalah individu, bukan lembaga. Tiga orang anggota KPU Provinsi Maluku Utara Masih bertugas. Selain itu, Pasal 8 ayat (3) UU No 22 tahun 2007 tentang Penyelenggaraan Pemilihan Umum menyebutkan bahwa tugas dan wewenang KPU dalam penyelenggaraan Pemilu Kepala Daerah dan Wakil Kepala Daerah meliputi: a) menyusun dan menetapkan pedoman tata cara penyelenggaraan sesuai dengan tahapan yang diatur dalam peraturan perundang-undangan; b) mengordinasikan dan

${ }^{13}$ Abdul Gaffar Karim (Editor), Kompleksitas Persoalan Otonomi Daerah di Indonesia, Cetakan I, Pustaka Pelajar, Yogyakarta, 3003, hlm. 185. 
memantau tahapan; c) melakukan evaluasi tahunan penyelenggaraan Pemilu; d) menerima laporan hasil Pemilu dari KPU Provinsi dan KPU Kabupaten/Kota; e) menonaktifkan sementara dan/atau mengenakan sanksi administrasi kepada anggota KPU Provinsi yang terbukti melakukan tindakan yang mengakibatkan terganggunya tahapan penyelenggaraan Pemilu yang sedang berlangsung berdasarkan rekomendasi Bawaslu dan ketentuan peraturan perundang-undangan; dan f) melaksanakan tugas dan wewenang lain yang diberikan oleh undang-undang.

Dari segi keabsahan, ada beberapa pendapat yang mengatakan bahwa rapat pleno KPU juga bermasalah. KPU mengadakan rapat pleno hanya dihadiri oleh 4 orang anggota, sementara 2 orang lainnya sedang menjadi pemantau pemilu di Australia. Padahal, dalam UU No 22 tahun 2007 Pasal 34 menegaskan bahwa, (1) Rapat pleno KPU sah apabila dihadiri oleh sekurang-kuraangnya 5 (lima) orang anggota KPU yang dibuktikan dengan daftar hadir; (2) Keputusan rapat pleno KPU sah apabila disetujui oleh sekurang-kurangnya 4 (empat) orang anggota KPU yang hadir; (3) Dalam hal tidak tercapai persetujuan sebagaimana dimaksud pada ayat (2), keputusan rapat pleno KPU diambil berdasarkan suara terbanyak. Tetapi, Pasal 36 ayat (1) menegaskan bahwa, dalam hal tidak tercapai kuorum, khusus rapat pleno KPU, KPU Provinsi, dan KPU Kabupaten/ Kota untuk menetapkan hasil Pemilu ditunda selama 3 (tiga) jam. Ayat (2) menegaskan, dalam hal rapat pleno telah ditunda sebagaimana dimaksud pada ayat (1) dan tetap tidak tercapai kuorum, rapat pleno dilanjutkan tanpa memperhatikan kuorum. Artinya, meskipun rapat pleno tidak memenuhi syarat sebagaimana ditentukan oleh Pasal 34 ayat (1), rapat pleno KPU dapat dinyatakan sah KPU pun tidak ingin membiarkan kasus pilkada di Maluku Utara tersebut berlarut-larut. Jadi, dari segi keabsahan rapat pleno KPU tidak perlu dipermasalahkan lagi.

Soal pemberhentian anggota KPUD, UU No 22 Tahun 2007 telah mengatur mekanisme pemberhentian seperti diatur dalam Pasal 30 ayat (1) yang menegaskan bahwa, pemberhentian anggota KPU, KPU Provinsi, dan KPU Kabupaten/Kota yang telah memenuhi ketentuan ... didahului dengan verifikasi oleh Dewan Kehormatan atas rekomendasi Bawaslu atau pengaduan masyarakat dengan identitas yang jelas. Padahal, sampai keputusan KPU tentang pemberhentian anggota KPUD tersebut Badan Kehormatan dimaksud belum terbentuk, anggota KPUD pun tidak diberi kesempatan untuk membela diri sebagaimana diatur dalam Pasal 30 ayat (2). KPU memberhentikan Ketua KPUD dan seorang anggota KPUD 
Maluku Utara dengan alasan, adanya pelanggaran janji dan sumpah jabatan. Selain itu dua orang tersebut dianggap tidak mematuhi petunjuk KPU Pusat dalam menyelesaikan kekisruhan Pilkada Maluku Utara. Alasan pemberhentian tersebut tidak sesuai dengan Pasal 31 UU No 22 Tahun 2007 yang mengatur pemberhentian anggota KPU, KPU Provinsi dan KPU Kabupaten/Kota.

Apabila kita kaji, Pasal 122 ayat (3) sebenarnya memberikan celah kepada KPU untuk mengambil alih tugas KPU Provinsi dan KPU Kabupaten. Tetapi, pengaturannya tidak jelas, dalam kondisi dan alasan apa KPU Pusat dapat mengambil alih tugas KPUD tersebut tidak diatur secara rinci. Apakah dapat dibenarkan apabila KPU bersandar pada Pasal 122 ayat (3) untuk mengambil alih kewenangan KPUD dan melakukan rekapitulasi pemungutan suara pemilihan Gubernur/Wakil Gubernur dalam hal ini pemilihan Gubernur/Wakil Gubernur Maluku Utara tahun 2007 dengan alasan rapat pleno KPUD Malut beberapa kali mengalami deadlock (jalan buntu), KPU pun menetapkan calon terpilih Gubernur/ Wakil Gubernur. Jelas bahwa, dalam persoalan ini KPU bertindak atas dasar pertimbangan dan penafsiran sendiri sebab, tidak ada satu pasal pun dalam UU No 32 Tahun 2004, PP No 6 Tahun 2007 dan UU No 22 tahun 2007, yang memberikan kewenangn kepada KPU Pusat untuk mengadakan rekapitulasi ulang, apalagi menetapkan pasangan calon terpilih Gubernur/Wakil Gubernur. Hal ini dapat dijadikan alasan untuk mementahkan keputusan KPU Pusat. Dalam Pasal 66 UU Nomor 32/ 2004, tugas dan wewenang KPUD dalam penyelenggaraan pemilihan kepala daerah dan wakil kepala daerah adalah menetapkan hasil rekapitulasi penghitungan suara dan mengumumkan hasil pilkada. Dalam UU Nomor 22/1007 pada Pasal 9 ayat (3) huruf j, tugas dan wewenang KPU Provinsi adalah menetapkan dan mengumumkan hasil pilkada berdasarkan hasil rekapitulasi penghitungan suara pilkada provinsi dari seluruh KPU kabupaten/kota dalam wilayah provinsi yang bersangkutan dengan membuat berita acara penghitungan suara dan sertifikat hasil penghitungan suara. Karena yang mempunyai otoritas dan kewenangan KPU provinsi, maka yang harus menjadi pegangan adalah hasil yang dikeluarkan KPU provinsi.

Lepas dari persoalan di atas, KPU juga mengeluarkan Peraturan KPU No 12 tahun 2007 tentang Perubahan Atas Keputusan KPU No 667 Tahun 2003 tentang Tata Kerja KPU, KPUD. Dalam peraturan tersebut diatur mengenai mekanisme untuk mengambil alih tugas KPUD, yang 
merupakan turunan dari Pasal 122 UU No 22 Tahun 2007. Menurut Saldi Isra, peraturan KPU tersebut tidak memiliki dasar hukum. Sebab, UU No 22 Tahun 2007 tidak memerintahkan KPU untuk menindaklanjuti dalam bentuk peraturan KPU. Ternyata, bukan kali ini saja KPU bertindak atas kehendak sendiri, KPU pernah melakukan "Onrechtmatige Overheidsdaad" dengan merubah UU tanpa melalui mekanisme prosedur yang berlaku. Menyandarkan demokratisasi pemilu kepada KPU ternyata KPU merubah sendiri payung hukum pemilu dengan cara yang tidak sah. ${ }^{14}$

Sengketa Pemilihan Kepala Daerah (Pilkada) Provinsi Maluku Utara tersebut akhirnya diajukan ke dua lembaga pengadilan yaitu Mahkamah Agung (MA) dan Mahkamah Konstitusi(MK). Di MA, pemohon, Thaib Armaiyn dan Abdul Gani Kasuba, yang diwakili Kuasa Hukumnya Andi M Asrun meminta para hakim agung menyatakan keputusan Komisi Pemilihan Umum (KPU) Pusat tentang penetapan calon terpilih gubernur dan wakil gubernur Maluku Utara tidak sah. "Menyatakan keputusan itu batal demi hukum,". Pasangan Thaib-Abdul Gani menyatakan tindakan KPU Pusat yang membatalkan keputusan KPU Provinsi Maluku Utara menunjukkan bahwa secara fakta hukum telah terjadi sengketa Pilkada. Pada petitum permohonannya, pemohon meminta MA menyatakan keputusan KPU Provinsi Maluku Utara sah dan memiliki kekuatan hukum yang mengikat. "Menetapkan Thaib Armaiyn dan Abdul Ghani sebagai gubernur dan wakil gubernur yang sah". Sedangkan kuasa hukum KPU Rufinus Hutauruk, mengatakan MA tidak berwenang menangani kasus tersebut karena MA hanya berwenang memeriksa sengketa Pilkada yang berkaitan dengan perhitungan suara. "Sedangkan permohonan ini substansinya tidak ada yang menyinggung tentang perhitungan suara.

Pada tanggal 22 Januari 2008, dalam sidang sengketa Pemilihan Kepala Daerah Provinsi Maluku Utara, Majelis Hakim Agung yang diketuai Paulus Effendy Lotulung memutuskan untuk melakukan perhitungan ulang di tiga kecamatan di Kabupaten Halmahera Barat (Jailoho, Ibu Selatan, dan Suhu Timur). Di samping itu, majelis hakim

${ }^{14}$ Lihat surat KPU Pusat No. 199/15/IV/2003 tertanggal 7 April 2003 yang ditujukan kepada Gubernur, bupati/walikota untuk meralat fofmulir KPU-2, sedangkan formulir KPU-2 sudah sesuai dengan Pasal 18 huruf (k) UU No 12 tahun 2003. Tataq Chidmad, Kritik Terhadap Pemilihan Langsung, Cetakan I, Pustaka Widiyatama, Yogyakarta, 2004 , hlm. 73-74 
juga menyatakan tidak sah dan membatalkan demi hukum SK KPU tentang penetapan Abdul Gafur- AR Fabanyo sebagai pasangan calon terpilih Gubernur dan Wakil Gubernur Maluku Utara. Hakim menilai bahwa pengambilalihan tahapan pilkada Maluku Utara oleh KPU cacat yuridis. Oleh karena itu, dengan putusan ini seluruh keputusan KPU Pusat antara lain soal penetapan kepala daerah, penonaktifan kinerja KPU Provinsi Maluku Utara juga batal. Alasan Hakim Agung untuk menggelar perhitungan ulang di tiga kecamatan di Kabupaten Halmahera Barat, karena yang dilakukan oleh KPU Provinsi Maluku Utara telah melanggar prosedur yaitu pengambilan keputusan tanpa rapat pleno. ${ }^{15}$

Sesuai dengan Keputusan MA yang sebelumnya membatalkan keputusan KPU Pusat dan meminta KPU Provinsi Malut untuk segera melakukan penghitungan ulang. Pada Hari Senin tanggal 11 Pebruari 2008, Ketua KPUD Maluku Utara Rahmi Husein melakukan penghitungan ulang di kecamatan Ibu Selatan, Sahu Timur, dan Jailolo. Abdul Gafur-Fabanyo dinyatakan menang di tiga kecamatan tersebut, namun secara keseluruhan, Pilkada Malut dimenangkan pasangan Thaib Armayn dan Abdul Gani. ${ }^{16}$

Dengan demikian, hasil penghitungan ulang tidak mengubah hasil penghitungan ulang Panitia Pemilihan Kecamatan (PPK) yang dilakukan pada 16 November 2007 di tiga kecamatan tersebut. Penghitungan ulang yang dilakukan di Jakarta, menegaskan keputusan SK No 20 KPUD Maluku Utara tertanggal 16 November 2007 menyatakan pasangan Thaib Armayn dan Abdul Gani sebagai pemenang pilkada Malut.

Penghitungan ulang di tiga kecamatan di Kabupaten Halmahera Barat yang dilakukan di Jakarta oleh Ketua KPUD Maluku Utara Rahmi Husein dinilai tidak sah oleh Ketua KPU Pusat Abdul Hafiz Anshary karena tiga alasan, Pertama, penghitungan ulang dilakukan oleh mereka yang telah diberhentikan sementara dari tugas sebagai ketua dan anggota KPUD Maluku Utara; kedua, prosedur penghitungan tidak sesuai dengan undangundang karena tidak memenuhi kuorum; ketiga, penghitungan tidak dilakukan di Halmahera Barat. Ini kesalahan MA tidak mencantumkan tempat di mana penghitungan ulang tersebut dilakukan. Masalah tempat ini penting ditetapkan, sebab apabila penghitungan suara dilakukan diluar

\footnotetext{
${ }^{15} \mathrm{http} / \mathrm{www} /$ Hukumonline.com. diakses tanggal 22 Januari 2008.

${ }^{16} \mathrm{http} / \mathrm{www} /$ menkokesra.go.id/content/view/7231/39
} 
tempat yang telah ditentukan dikategorekan telah melakukan penyimpangan dan menjadi sebab dilakukannya penghitungan ulang, sesuai dengan ketentuan PP No 6 tahun 2005 tentang Pemilihan, Pengesahan, Pengangkatan dan Pemberhentian Kepala Daerah dan Wakil Kepala Daerah Pasal 90 ayat (d) penghitungan ulang surat suara di TPS dilakukan apabila dari hasil penelitian dan pemeriksaan terbukti terdapat satu atau lebih penyimpangan yaitu, penghitungan suara dilakuka di luar tempat dan waktu yang telah ditentukan. Sementara itu, Pelaksana tugas Ketua KPUD Maluku Utara Mukhlis Tapi tapi juga menggelar rekapitusai ulang di Ternate dan menetapkan pasangan Abdul Gafur dan Abdurahim fabanyo sebagai Gubernur serta Wakil Gubernur terpilih. ${ }^{17}$

Dengan demikian, sebagai tindak lanjut dari perintah Mahkamah Agung untuk melakukan penghitungan ulang terdapat dua versi yaitu, versi KPU Maluku Utara yang dipimpin oleh Mukhlis Tapitapi (yang diakui oleh KPU Pusat) dan versi KPU Maluku Utara yang dipimpin oleh Rahmi Husein (yang diberhentikan KPU Pusat dan tidak diakui keabsahannya oleh KPU Pusat).

Terhadap dua versi hasil penghitungan suara tersebut pada tanggal 26 Pebruari 2008, Menteri Dalam Negeri mengirimkan surat guna meminta fatwa kepada Mahkamah Agung (MA). Pada tanggal 10 Maret 2008 MA mengeluarkan fatwa untuk menjawab surat Mendagri tersebut. Dalam fatwanya MA menilai penghitungan yang dilakukan Ketua dan anggota KPU Maluku Utara, yaitu Rahmi Husein dan Nurbaya Suleman telah memenuhi prosedur hukum acara perdata. Fatwa itu menyebutkan prosedur dan tata cara eksekusi pelaksanaan penghitungan suara mengikuti ketentuan Hukum Acara Perdata, yakni harus didahului dengan permohonan eksekusi ke Ketua Pengadilan dan diikuti dengan penetapan eksekusi. Dalam penghitungan yang dilakukan oleh Ketua KPU Maluku Utara Rahmi Husein hadir Ketua Pengadilan Tinggi Maluku Utara dan ikut menandatangani hasil penghitungan suara. Fatwa itu juga didasarkan pada putusan MA yang menilai pengambilalihan oleh KPU yang didasarkan kepada UU No. 22 tahun 2007 Pasal 122 ayat (1) maupun ayat (3) tidak dapat dibenarkan dan cacat yuridis. Surat keputusan, termasuk segala putusan dan produk hukum yang bersifat derivatif dari putusan itu tidak sah dan harus dibatalkan (termasuk didalamnya

\footnotetext{
${ }^{17}$ http:/ / www.depdagri.go.id diakses tanggal 28 Maret 2008)
} 
keputusan penonaktifan ketua KPU Maluku Utara Rahmi Husein dan anggotanya Nurbaya Suleman).

Berdasarkan hasil fatwa tersebut Mendagri berkonsultasi kepada Presiden dan Wakil Presiden untuk menentukan langkah selanjutnya. Hasil rapat kebinet terbatas tersebut memutuskan untuk menyerahkan persoalan Pilkada Maluku Utara kepada DPRD Maluku Utara.

Pada tanggal 16 April 2008, rapat paripurna Dewan Perwakilan Rakyat Daerah (DPRD) Maluku Utara (Malut) di Ternate memutuskan menguatkan surat pengusulan Gubenur dan Wakil Gubernur Malut terpilih hasil Pilkada Malut yang dibuat DPRD Malut pada 20 Februari 2008. Surat tanggal 20 Februari 2008 itu mengusulkan agar pasangan Abdul Gafur-Abd Rahim Fabanyo dilantik sebagai Gubernur dan Wakil Gubenur Malut yang dihasilkan melalui penghitungan ulang pilgub Maluku Utarat oleh Plt Ketua KPUD Malut Mukhlis Tapi Tapi.

Rapat paripurna yang dihadiri 20 anggota DPRD Malut itu juga menyatakan seluruh surat DPRD yang bertentangan dengan hasil paripurna itu dicabut. Rapat dipimpin dua Wakil Ketua DPRD Malut, Syaiful B Ruray dan Abd Rahim Fabanyo. Ketua DPRD Malut Ali Syamsi tidak menghadiri rapat paripurna itu. Pimpinan DPRD bersifat kolektif, dan rapat yang diikuti 20 anggota DPRD itu telah kuarom (jumlah keseluruhan anggota DPRD Maluku Utara 35 orang. Sedangkan 14 (empat belas) anggotya DPRD tidak hadir dan 1 (satu) anggota berhalangan hadir karena sakit. ${ }^{18}$

Namun, pada hari yang sama yakni Rabu sore, 15 anggota DPRD lainnya mengadakan rapat terpisah dan merekomendasikan pasangan Thaib Armayn-Gani Kasuba sebagai gubernur dan wagub terpilih. ${ }^{19}$ Menyikapi persoalan di atas, Ketua Mahkamah Konstitusi (MK) Jimly Ashidiqqie menyatakan, sengketa hasil pemilihan kepala daerah di Maluku Utara sebenarnya dapat segera diselesaikan dengan cara melaksanakan sepenuhnya putusan Mahkamah Agung (MA). Sebab, MA merupakan satu-satunya lembaga yang berhak menangani sengketa pilkada yang terjadi sebelum Oktober 2009. Sebab, dalam perubahan kedua atas UU Nomor 32 Tahun 2004 tentang Pemerintahan Daerah, yang disetujui DPR pada 1 April 2008 menyatakan, penanganan sengketa hasil pilkada oleh MA dialihkan ke MK paling lama 18 bulan sejak UU itu

\footnotetext{
${ }^{18}$.ttp/www.Republika.co.id . diakses tanggal 16 April 2008)

${ }^{19}$ (http.www. republika.co.id. diakses tanggal 18 April 2008)
} 
diundangkan. ${ }^{20}$

Pada tanggal 2 Juni 2008 Menteri dalam Negeri menetapkan Thaib Armiyn-Abdul Gani Kasuba sebagai Gubernur dan Wakil Gubernur Maluku Utara. Keputusan pemerintah didasarkan pada fatwa Mahkamah Agung tanggal 10 Maret 2008 yang menyatakan bahwa penghitungan ulang di Hotel Karsa Bidara, Jakarta sesuai dengan hukum acara perdata. Dasar lainnya yaitu fatwa MA tanggal 14 Mei 2008 bahwa pemerintah berhak mengambil keputusan atas sengketa hasil pemilihan kepala daerah.

Di Mahkamah Konstitusi, permohonan Sengketa Kewenangan Lembaga Negara (SKLN) diajukan oleh Ketua KPUD Maluku Utara, M Rahmi Husen meminta agar hakim konstitusi menyatakan KPU Pusat tidak memiliki wewenang untuk menetapkan pasangan gubernur dan wakil gubernur dengan cara membuat rekapitulasi dan penghitungan suara ulang. KPU Provinsi Maluku Utara adalah pihak yang memiliki kewenangan untuk menyelenggarakan seluruh proses dan tahapan pemilihan gubernur dan wakil gubernur. Hal ini akan berbeda manakala MK memasukkan Pilkada ke dalam rezim, di mana penyelenggara pemilu adalah KPU dengan segala konsekuensinya. ${ }^{21}$ Perkara sengketa kewenangan lembaga negara (SKLN) antara Komisi Pemilihan Umum Daerah dengan Komisi Pemilihan Umum Pusat akhirnya dicabut oleh pemohon untuk menghindari kontroversi adanya putusan berbeda dari dua lembaga (MA dan MK).

${ }^{20}$ (http/www. Kompas. Com. Diakses tanggal 18 April 2008)

${ }^{20}$ Lihat Abdul Mukti Fadjar, Hukum Konstitusi dan Mahkamah Konstitusi, Konstitusi Press Jakarta dan Citra Media Yogyakarta, Cetakan Pertama, 2006, hlm. 112-120. Secara definisi, pemilihan kepala daerah tidak dirumuskan secara tersurat sebagai pemilihan umum tetapi secara substansi seluruh asas dan proses penyelenggaraan kepala daerah adalah pemilihan umum. Lihat Ramlan Surbakti, Pemilihan Kepala Daerah Langsung oleh Rakyat Merupakan Bagian dari Pemilihan Umum, dalam Fathoni Mahar M (Editor), Agenda Pilkada dan Kesiapan Masyarakat Daerah, Lembaga Studi Pengembangan Partisipasi Publik dan Reforma Anggaran (LSP3RA), Boyolali, Cetakan I, 2004, hlm. 11. Lihat juga Putusan Mahkamah Konstitusi RI No. 072-073/ PUU-II/ 2004 tentang Pengujian UU No 32 tahun 2004 tentang Pemerintahan Daerah. 


\section{Penutup}

Berdasarkan uraian di atas dapat disimpulkan bahwa, terjadinya sengketa Pilkada Gubernur di Maluku Utara disebabkan tidak adanya payung hukum yang memberikan kepastian dalam menangani sengketa Pilkada. Masing-masing pihak bertindak sesuai dengan penafsirannya sendiri. Sebenarnya, keinginan para pihak untuk menang dengan berbagai cara dapat ditekan manakala ada acuan yang jelas, tegas dan tidak multitafsir, sehingga bagaimana pun juga sengketa Pilkada terjadi, semua dapat ditangani dengan mudah.

\section{Daftar Pustaka}

Abdul Gaffar Karim (Editor), Kompleksitas Persoalan Otonomi Daerah di Indonesia, Pustaka Pelajar, Yogyakarta, Cetakan I, 3003

Abdul Mukti Fadjar, Hukum Konstitusi dan Mahkamah Konstitusi, Konstitusi Press Jakarta dan Citra Media Yogyakarta, Cetakan Pertama, 2006

Ari Pradhanawati (Penyunting), Pilkada Langsung Tradisi Baru demokrasi Lokal, Konsorsium Monitoring dan Pemberdayaan Institusi Publik (KOMPIP), Surakarta, Cetakan Pertama, 2005

Bagir Manan, Menyongsong Fajar Otonomi Daerah, FH UII Yogyakarta, Cet.III, 2004

Fathoni Mahar M (Editor), Agenda Pilkada dan Kesiapan Masyarakat Daerah, Lembaga Studi Pengembangan Partisipasi Publik dan Reforma Anggaran (LSP3RA), Boyolali, Cetakan I, 2004

Jimly Asshiddiqie,"Pemilihan Langsung Presiden dan Wakil Presiden," Jurnal Unisia No 51/XXVII/I/2004

Joko J. Prihatmoko, Pemilihan Kepala Daerah Langsung Filosofi, Sistem dan Problema Penerapan di Indonesia, kerja sama Pustaka Pelajar dengan LP3M Universitas Wahid Hasyim Semarang, Cetakan I, Yogyakarta, 2005

Morison, Hukum Tata Negara Era Reformasi, Ramdina Prakarsa, Jakarta, 2005

Ni'matul Huda, Otonomi Daerah Filosofi, Sejarah Perkembangan dan Problematika, Pustaka Pelajar, Cetakan I, Yogyakarta, 2005

Tataq Chidmad, Kritik Terhadap Pemilihan Langsung, Pustaka Widiyatama, Yogyakarta, Cetakan I, 2004

Undang-Undang No 32 Tahun 2004 tentang Pemerintahan Daerah 
Undang-Undang No 22 Tahun 2007 tentang Penyelenggaraan Pemilihan Umum

Peraturan Pemerintah No. 6 Tahun 2005 tentang Tata Cara Pemilihan, Pengesahan, Pengangkatan, dan Pemberhentian Kepala Daerah.

Putusan Mahkamah Konstitusi RI No. 072-073/PUU-II/2004 tentang Pengujian UU No 32 tahun 2004 tentang Pemerintahan Daerah.

Sindu, 23 November 2007

Tempo, 23 November 2007

http:/ / www.tempointeraktif.com.

http:/ / bintannews.com

www.Kabarindonesia. Com.20 November 2007, 13:35:50 WIB.

http.www/Republika.co.id

www/http/Hukumonline.com. diakses tanggal 22 Januari 2008.

http/www/menkokesra.go.id/content/view/7231/39 